\title{
ABSTRACTS
}

\section{The International Criminal Court and the question of alternative justice system in Africa: a case of be careful of what you wish for?}

\author{
By Charles Majinge, Dar-Es-Salaam / Heidelberg
}

This article attempts to analyze the role of the international criminal court in prosecuting serious crimes in Africa vis a vis the whole concept of alternative justice or complementarity principle as enshrined in the Rome Statute. In this article it is argued that for Africa to move forward and realize its development potential then the work of the international criminal court will be critical in the fight against impunity to consolidate rule of law and democracy. It is further argued that the court should be cautious when determining whether alternative justice system used by countries to address past crimes meet the standards of justice espoused by the Rome Statute because countries have different understanding of justice as such it may create conflict between countries whose support the court cannot succeed without. It is argued that alternative justice mechanisms which do not condone impunity for crimes within the jurisdiction of the court should be accepted as long as the aim is to further justice and reconciliation.

It is further argued that the court must balance between the legitimate desire of countries to achieve peace and justice after conflict through their domestic means with the international legal duty of countries especially parties to the Rome Statute to genuinely prosecute international crimes falling in the domain of the court. The success of the court will partly depend on how successful it manages to form and sustain strong partnership with important organizations like African Union, IGAD or SADC among others not only for these organizations to take proactive steps to encourage member states to address violations of serious crimes within their countries but also to garner their support in enforcing the court's decisions. Further, the court should support domestic justice mechanisms by offering assistance to the national institutions such as judiciary and national human rights commissions in areas such as investigation techniques, ant impunity strategies, collection and storage of evidence and general knowledge sharing. This partnership can in a long term enhance the capability of these institutions to address serious crimes at a national level and in the process fostering peace and justice without involvement of ICC.

Lastly, the article emphasizes the need of the state parties to take their obligations and commitments seriously by affording the court assistance it may need to fulfill its mandate and also avoiding signing peace agreements which they well know to be inconsistent with their obligations to the Rome Statute. 


\title{
The Southern African Development Community (SADC) and its Tribunal: Reflexions on a Regional Economic Communities' Potential Impact on Human Rights Protection?
}

\author{
By Oliver C. Ruppel, Windhoek
}

Human-rights-related matters play a vital role within Regional Economic Communities. The Southern African Development Community (SADC) is such a Regional Economic Community counting a total population of more than 245 million with 15 states among its members, namely Angola, Botswana, the DRC, Lesotho, Madagascar, Malawi, Mauritius, Mozambique, Namibia, the Seychelles, South Africa, Swaziland, Tanzania, Zambia, and Zimbabwe. At first glance it might appear that the promotion and protection of human rights are not SADC top priority as an organisation that furthers socio-economic cooperation and integration as well as political and security cooperation. However, the protection of human rights is essential for economic development as it has an impact on the investment climate, which in turn contributes to growth, productivity and employment creation, all being essential for sustainable reductions in poverty. A wide range of provisions and objectives within the SADC legal system offer human rights protection inter alia in the SADC Treaty and the various SADC Protocols. The SADC Tribunal is the regional judicial institution within SADC. It was established to protect the interests and rights of SADC member states and their citizens, and to develop community jurisprudence, also with regard to applicable treaties, general principles, and rules of public international law. Although the primary aim of the Tribunal was to resolve disputes arising from closer economic and political union, rather than human rights, a recent judgement by the Tribunal and some of the pending cases demonstrate that the Tribunal can also be called upon to consider human rights implications of economic policies and programmes.

\section{Can paralegals enhance access to justice? The example of Morogoro Paralegal Centre in Tanzania}

\section{By Eva Diehl, Berlin}

This contribution analyses paralegal activities in Tanzania in the context of ongoing legal reforms aimed at improving access to justice. Paralegals are lay legal advisors trained by non-governmental organisations to engage in legal aid and legal education activities, with the aim of raising awareness about certain national laws as well as international human rights. Proponents of paralegals argue that their voluntary services do not only have advantages in terms of financial and geographical accessibility, but that paralegals can also practise forms of alternative dispute resolution which are culturally more accepted by the population than the procedures in court. Paralegals in Tanzania operate in a legally plural context where different conceptions of justice are at play. The present analysis is focused on a paralegal centre in Morogoro, which is shown to fulfil various functions: it facilitates 
mediated settlements outside the courts, it accompanies and counsels clients in court cases, and it acts as a switch-point delegating clients to other institutions in a network of forums with partly overlapping jurisdictions. It is concluded that while paralegals are able to make some contributions towards improved access to justice in small cases and family disputes within and outside the courts, they are little powerful in the face of abounding corruption or cases involving powerful officials.

\section{Under Reconstruction: Ethnicity, Ethnic Nationalism, and the Future of the Nigerian State}

\section{By Isiaka Alani Badmus, Lagos}

This article, using a diachronic approach, advances the argument that a genuine national cohesion and the future of the Nigerian state cannot be fully guaranteed in the clear absence of addressing the inherent structural defects of the country's malfunctioning federalism. The Nigerian post-colony is, presently, confronted by the challenges pose by ethnicity/ ethnic nationalism with negative consequences of political ethnicity, ethnic conflicts, etc. It is argued that the entrenchment of plural democracy has the capacity to address the lopsided policies of the central state that are at the peril of the weak federating states and most importantly, the oil-bearing ethnic minorities of Nigeria's Niger Delta. In addendum, the article argues and demonstrates that democracy in the real sense of has the potency of democratising the Nigerian nation-state; strengthening of mediatory and regulatory institutions; promoting intra-and inter- ethnic relations; etc. The agitations and activities of the oil-bearing ethnicities and various ethnic social movements of the Nigeria's Fourth Republic for autonomy and social justice were used to buttress this article's basic augments and concludes with the government's efforts in addressing Africa's most popular country's multilayered ethnic problems.

\section{Transition to democracy and party bans, or: Why is there no party ban provision in the South African constitution?}

\section{By Jörg Kemmerzell, Darmstadt}

The introduction or re-introduction of multi party systems in Sub-Saharan Africa between 1989 and 1994 has been widely accompanied by the fear, that the new institutional order might promote or award the politicisation of particularistic identities. This might be one reason for the heavy de jure and de facto restrictions of the activities of political parties in many African countries. At least 40 of 48 states in the region provide for the legal possibility of party bans. South Africa remains one of the few African countries that abstained from the adoption of party ban provisions. This seems remarkable not only because of the countries history of violent ethnic conflict, but also of the Apartheid system representing a 
background as a historical and ubiquitous denounced unjust regime. I will give first a short introduction into the concept of party ban (section $\mathrm{B}$ ). In section $\mathrm{C}$ possible reasons and justifications in favour of a restrictive regulation of party politics will be discussed, highlighting the course of South Africa's transition to democracy (1990-1994). Section D puts the crucial legal norms in the body of South African constitutional and public law under investigation. After that I will develop and examine three hypotheses, which help to explain the abandonment of legal provisions for party bans in South Africa. The hypotheses refer first to the specific historical experience with bans on political organisations during Apartheid rule, secondly the coordinated transition to democracy, promoting the value of inclusiveness as one of its central pillars, and thirdly the commensurability of measures restricting political liberties against a background of threats to the developing democratic order. This main section is based partially on interviews with experts on South African politics and constitutional law. The article concludes with an explanation of the issue, which exhibits motives from the literature on democratic transition, and a tentative comparative forecast. 